\title{
REVIEW
}

\section{Aging- and gender-related modulation of RAAS: potential implications in COVID-19 disease}

\author{
Laura Monteonofrio ${ }^{1, *}$, Maria Cristina Florio1,*, Majd AlGhatrif1,2,3, Edward G Lakatta1 and Maurizio C Capogrossi1,3 \\ 'Laboratory of Cardiovascular Science, National Institute on Aging, National Institutes of Health, Baltimore, Maryland, USA \\ 2Longitudinal Study Section, National Institute on Aging, National Institutes of Health, Baltimore, Maryland, USA \\ 3Division of Cardiology, The Johns Hopkins University School of Medicine, Baltimore, Maryland, USA \\ Correspondence should be addressed to M C Capogrossi: mcapogr1@jhmi.edu \\ *(L Monteonofrio and M C Florio contributed equally to this work)
}

\begin{abstract}
Coronavirus disease 2019 (COVID-19) is a new infectious disease caused by severe acute respiratory syndrome coronavirus 2 (SARS-CoV-2). COVID-19 is frequently characterized by a marked inflammatory response with severe pneumonia and respiratory failure associated with multiorgan involvement. Some risk factors predispose patients to develop a more severe infection and to an increased mortality; among them, advanced age and male gender have been identified as major and independent risk factors for COVID-19 poor outcome. The renin-angiotensin-aldosterone system (RAAS) is strictly involved in COVID-19 because angiotensin converting enzyme 2 (ACE2) is the host receptor for SARS-CoV-2 and also converts pro-inflammatory angiotensin (Ang) II into anti-inflammatory Ang(1-7). In this review, we have addressed the effect of aging and gender on RAAS with emphasis on ACE2, pro-inflammatory Ang II/Ang II receptor 1 axis and anti-inflammatory Ang(1-7)/Mas receptor axis.
\end{abstract} Key Words

- COVID-19

- aging

- gender

- cardiovascular disease

- ACE2

\section{Introduction}

Coronavirus disease 2019 (COVID-19) has been recently recognized as a new infectious disease caused by severe acute respiratory syndrome coronavirus 2 (SARS-CoV-2). COVID-19 emerged in China in 2019 and rapidly spread throughout the globe; on March 11, 2020, the World Health Organization declared the COVID-19 outbreak a pandemic. Most COVID-19 patients are asymptomatic or have minimal symptoms, however, some patients develop severe pneumonia, acute respiratory distress syndrome (ARDS) and multiorgan damage frequently leading to the patient's demise $(1,2,3,4)$.

SARS-CoV-2 belongs to the Coronaviridae family that also includes severe acute respiratory syndrome coronavirus (SARS-CoV), first reported in China in 2002
(5), and middle east respiratory syndrome coronavirus (MERS-CoV), first described in Saudi Arabia in 2012 (6); both SARS-CoV and MERS-CoV can cause severe pneumonia.

The recent emergence of COVID-19 as a global health threat has prompted increased interest in the risk factors involved in COVID-19 poor outcomes. The first retrospective multicenter cohort study of COVID-19 in Wuhan, identified older age as a significant risk factor for in-hospital mortality (2). A CDC report from July 2020 describes the demographic characteristic of 52,166 deceased COVID-19 patients. Among these, 55.4\% are males and $79.6 \%$ are older than 65 years (7). Further, the fatality rate is age-related: the highest fatality rate is

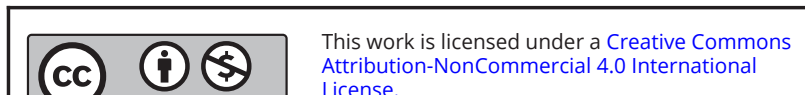
License. 
seen in persons older than 85 years (30.9\%), followed by persons aged 75-84 years (27.1\%) and persons aged 65-74 years $(21.6 \%)(7)$.

Epidemiologic studies also identified male gender as a risk factor for poor outcome of COVID-19 disease. On August 7, 2020, an independent and internationally recognized initiative to advance action for gender equality (Global health 50/50), collected official data regarding sex prevalence in confirmed cases of COVID-19 in 66 counties. 32 countries reported a slightly higher number of cases in men, 9 had a similar incidence in both men and women, and 25 with a slightly higher number of cases in women (pages accessed on September 6th, 2020: https:// globalhealth5050.org/covid19/sex-disaggregated-datatracker/; https://globalhealth5050.org/covid19/age-andsex-data/\#1589893682295-1abaac66-2013). Although the gender-related infection rate can be different in each country, overall, male patients are highly prone to develop a more severe illness with a higher fatality rate, especially subjects older than 60 years $(2,4,8,9)$. Recently, a comparative analysis of COVID-19 case fatality rates (CFR) by sex and age in 38 countries showed that the average male CFR is 1.7 times higher than female (10). Moreover, it confirmed that both sexes exhibit an increased risk of death with advancing age, with males having a significantly higher fatality outcome than females (10).

The mechanisms responsible for the effects of aging and male gender, as independent risk factors $(11,12,13)$, on morbidity and mortality of COVID-19 disease are still unknown. However, the renin-angiotensin-aldosterone system (RAAS) is strictly involved in COVID-19 and may play a role in aging- and gender-related differences in the severity of the infection.

\section{Angiotensin converting enzyme 2 (ACE2) the virus gateway into the cells}

In 2003, angiotensin converting enzyme 2 (ACE2), a pivotal anti-inflammatory component of the RAAS, was identified as the virus receptor on epithelial cells (14). ACE2 is the host receptor for SARS-CoV and plays an essential role in the development of the severe acute respiratory syndrome caused by SARS-CoV, both by facilitating virus internalization in lung epithelial cells and by acting as a protective mechanism against lethal lung failure $(14,15,16)$. Similar to SARS-CoV, SARS$\mathrm{CoV}-2$ requires the binding of the virus with its spike (S) glycoprotein to the membrane-bound form of ACE2 and the subsequent internalization of the complex by the host cell (Fig. 1). The host serine protease transmembrane serine protease 2 (TMPRSS2) cleaves the spike protein into S1 and S2 fragments, thus enabling fusion of viral and cellular membranes and facilitating viral entry $(17,18)$. The virus entry into the cell along with the membrane receptor ACE2, which is functionally removed from the external site of the membrane $(15,16)$. Interestingly, ACE2 affinity is ten-fold higher for SARS-CoV-2 than for SARS-CoV $(19,20)$.

\section{Beyond the gateway ACE2 as a tool for cell injury}

Virus-binding to ACE2 was also found to be implicated in cell injury and the development of ARDS. ACE2 is a key enzymatic component of RAAS, it converts proinflammatory angiotensin (Ang) II into anti-inflammatory $\operatorname{Ang}(1-7)$ (21) (Fig. 2). When bound by the virus, ACE2 is internalized by the cell leading to downregulation of ACE2 on the cell surface, in turn, increasing pro-inflammatory Ang II and decreasing anti-inflammatory Ang(1-7) $(14,15,16,22)$.

Since ACE2 is a key player in SARS-CoV-2 infection, in this review we examine the effect of aging and gender on RAAS with emphasis on ACE2 and on the balance of proinflammatory Ang II and anti-inflammatory Ang(1-7).

\section{RAAS signaling cascade}

Activation of RAAS cascade begins with prorenin and renin secretion that occur mostly in the kidney (23) (Fig. 2). Renin is secreted as a precursor protein named prorenin.
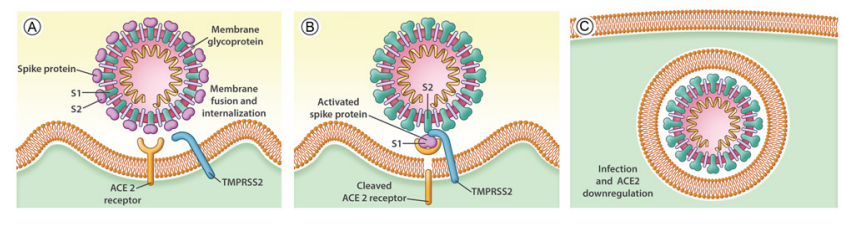

Figure 1

Mechanism of SARS-CoV-2 infection. (A) The virus infects cells through its spike protein by binding to ACE2 receptor with the complementary action of TMPRSS2. (B) The S protein is composed of two subunits: $S 1$ is the receptor-binding subunit, S2 the fusion subunit. S1 binds ACE-2 receptor, that is cleaved by TMPRSS2, thus activating the spike protein, and promoting the viral entry. (C) SARS-CoV-2 RNA is then released into the cytoplasm and viral replication is efficiently processed. ACE, angiotensinconverting enzyme; ACE2, angiotensin-converting enzyme 2; Ang, angiotensin; AT1R, angiotensin II type 1 receptor; AT2R, angiotensin II type 2 receptor; TMPRSS2, Transmembrane protease, serine 2 . 


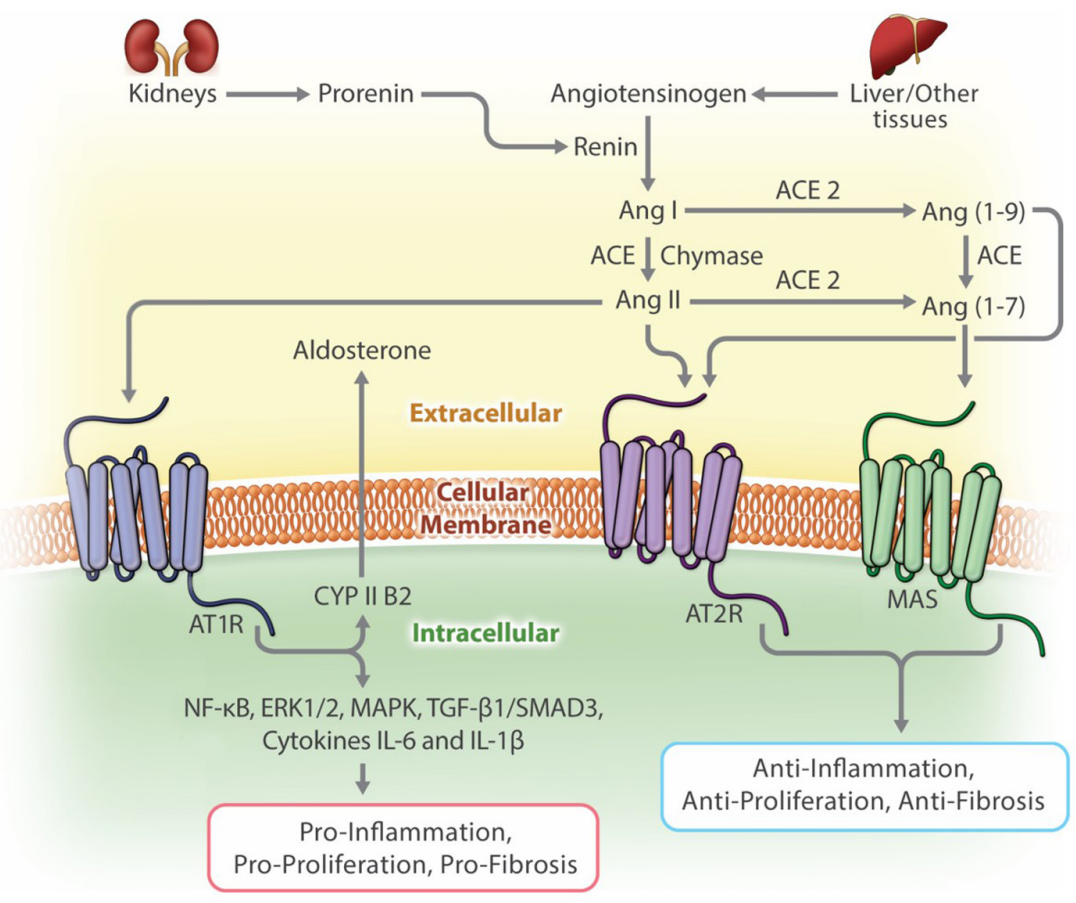

\begin{abstract}
Figure 2
Renin-angiotensin-aldosterone system. Renin secretion is the first step in the activation of the RAAS pathway. Renin cleaves angiotensinogen to form Ang I, which is then transformed into Ang II by ACE and chymase enzyme. Specific receptors, AT1R and AT2R, can then bind Ang II. AT1R stimulates blood pressure, cardiac remodeling, and atherosclerosis, whereas AT2R has opposite effects. ACE2 cleaves Ang I and Ang II to form Ang(1-9) to Ang(1-7), respectively. Ang(1-7) induces vasodilation, anti-inflammatory, antifibrotic, and anti-remodeling effects, through MasR and AT2R. ACE, angiotensin-converting enzyme; ACE2, angiotensin-converting enzyme 2; Ang, angiotensin; AT1 R, angiotensin II type 1 receptor; AT2R, angiotensin II type 2 receptor; MasR, Mas receptor.
\end{abstract}

Both prorenin and renin can bind to their specific receptor called prorenin-renin receptor (PRR) and activate intracellular pathways, triggering pro-fibrotic effects (24, $25)$. In the classical pathway, angiotensinogen produced primarily by the liver is converted into the decapeptide angiotensin I (Ang I) by renin (23). Subsequently, Ang I is cleaved by angiotensin converting enzyme (ACE) to produce the major effector of this system, the octapeptide angiotensin II (Ang II), which binds two G-protein coupled receptors, angiotensin II type 1 receptor (AT1R) and type 2 receptor (AT2R) (26). In the heart, the majority of Ang I is converted by the chymase enzyme (27).

AT1R stimulation increases the influx of extracellular $\mathrm{Ca}^{2+}$ inducing vascular smooth muscle cells (VSMCs) contraction and vasoconstriction (28), and enhances myocardial contractility (29). In the adrenal gland, Ang II induces aldosterone secretion, which increases tubular sodium reabsorption in the kidney and the effective circulating plasma volume by binding the mineralocorticoid receptor (30). Thus, under normal physiologic conditions, Ang II raises arterial blood pressure via a direct vasoconstrictive action and by inducing sodium and water retention via increased aldosterone production $(28,31)$.

RAAS signal transduction is mediated and balanced by Ang II-induced activation of AT2R, which antagonizes the Ang II/AT1R axis by (i) activating phosphotyrosine phosphatases (PTP) and subsequent inactivation of their growth-promoting effectors (32) and (ii) by inducing nitric oxide (NO) production and vasodilation (33). Further, the classical ACE/Ang II/AT1R axis is counter regulated by the antagonizing ACE2/Angiotensin(1-7)/Mas receptor (MasR) axis that opposes the classical actions of RAAS mediated via the AT1R (34).

\section{Ang II/AT1R/AT2R in inflammation and fibrosis}

Enhanced Ang II production induced by chronic activation of RAAS plays a major role in cardiovascular remodeling. In VSMCs, Ang II induces a phenotypic switch from a contractile to a proliferative and synthetic phenotype, that leads to vascular injury due to VSMCs hypertrophy/ proliferation and to the production of pro-inflammatory and pro-fibrotic mediators (35).

Ang II also induces endothelial cell apoptosis and dysfunction via AT1 receptor (36). Different signaling pathways and mechanisms are responsible for the effect of RAAS on cardiac and vascular remodeling.

Ang II binding to AT1R activates phospholipase C (PLC), phospholipase A (PLA), and phospholipase D (PLD). PLC $\beta$ induces the formation of diacylglycerol (DAG) and inositol 3-phosphate (IP3), that activate sodium-proton $\left(\mathrm{Na}^{+} / \mathrm{H}^{+}\right)$exchange leading to $\mathrm{Ca}^{2+}$ release from the endoplasmic reticulum and intracellular alkalinization, respectively. In addition, the increase in cytosolic $\mathrm{Ca}^{2+}$ induces pathological cardiac and vascular hypertrophy

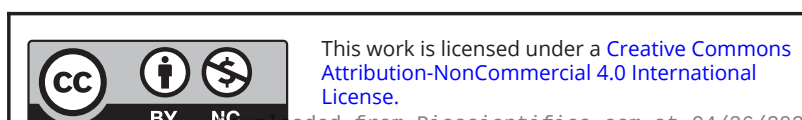
Attribution-NonCommercial 4.0 International

ded from Bioscientifica.com at 04/26/2023 10:25:52AM 
through calcium/calmodulin-dependent protein kinase II (CAMK2) and calcineurin-nuclear factor of activated $\mathrm{T}$ cells (NFAT) cascades $(37,38)$.

AT1R signaling activates different mitogen-activated protein (MAP) kinases, including extracellular signalregulated kinases (ERK1/2 and ERK5), c-Jun N-terminal kinases (JNK), and p38-MAP kinase. ERK1/2 and ERK5 are key growth signaling molecules both in VSMCs and fibroblasts, whereas JNK and p38-MAP kinase modulate cell survival, apoptosis, differentiation, and inflammation $(39,40,41)$. Ang II induces phosphorylation of a variety of tyrosine kinases including c-Src, janus family kinase (JAK) and phosphatidylinositol 3-kinase (PI3K) (42, 43). Ang II also transactivates tyrosine kinase receptors including platelet-derived growth factor receptor (PDGFR), insulin-like 1 growth factor receptor (IGF-1R), and EGF receptor (EGFR) via activation of tyrosine kinase, production of reactive oxygen species (ROS), and activation of metalloprotease (MMPs) (44, 45). Among MMPs, A Disintegrin and Metalloproteinase 17 (ADAM17) contributes to RAAS signaling both by transactivating EGFR (46) and shedding/inactivating ACE2 (47, 48). In VSMCs, in endothelial cells, and in cardiac cells, Ang II-activated EGFR induces fibrosis by mediating fibronectin synthesis, MMPs production, breakdown of collagen IV and expression of plasminogen activator inhibitor-1 (49). In addition, AT1R directly increases transforming growth factor beta1 (TGFB1) resulting in nuclear translocation of SMAD proteins 2, 3 and 4, and expression of fibrotic marker proteins, that is, collagen, fibronectin, and connective tissue growth factor (CTGF). The latter is a critical profibrotic mediator implicated in fibroblast proliferation, cellular adhesion, and extracellular matrix protein (ECM) synthesis $(50,51,52,53)$.

Ang II directly increases oxidative stress by activating membrane dihydronicotinamide-adenine dinucleotide phosphate and hydrate oxidase (NADPH and $\mathrm{NADH}$, respectively), mainly via AT1R, to produce ROS, superoxide and hydrogen peroxide $\left(\mathrm{H}_{2} \mathrm{O}_{2}\right)$ (31). ROS mediate most of the pathophysiological effects of Ang II through the activations of growth-promoting and pro-inflammatory signaling molecules, including c-Src, EGFR, p38MAPK, and transcription factors including nuclear factor $\mathrm{kB}$ (NF-kB).

Ang II exerts its pro-inflammatory actions also by activating leukocytes, lymphocytes, and macrophages that in turn produce cytokines and chemokines. Through AT1R, Ang II mediates activation of CD34+ T helper cells, important for the adaptative immune response. Specifically, all three $\mathrm{T}$ helper cell subclasses, that is, Th1, Th2, and Th17, secrete Interferon (IFN)- $\gamma$, interleukin (IL)-4, IL-17, and, via these mediators induce hypertension (54) and cardiac fibrosis (55). Ang II stimulation of mouse macrophage cell lines results in Nuclear factor $\kappa \mathrm{B}(\mathrm{NF}-\kappa \mathrm{B})$ and activator protein 1 (AP-1) activation, ROS production, and secretion of inflammatory cytokines including tumor necrosis factoralpha (TNF-A), IL-1B, IL-6, and the anti-inflammatory IL-10 (56). AT1R-dependent IL-6 production has been found in a rat lung macrophage cell line and mediates kidney injury (57). Moreover, Ang II infusion in the mouse increases plasma IFNG, TNF-A, IL-1, IL-6 (58). Interestingly, Ang II-dependent release of IL-6 induces microvascular injury leading to thrombo-inflammatory responses (59).

It is noteworthy that pro-inflammatory and profibrotic mediators induced by Ang II are involved in pathophysiological lung remodeling (60). Transgenic mice with chronic activation of RAAS spontaneously develop progressive lung fibrosis, independently of blood pressure, with a marked decline in pulmonary function (61). Ang II-mediated activation of AT1R and AT2R in lung parenchyma, enhance lung remodeling and fibrosis (62). In lung fibroblasts, miR-21 induced by Ang II activates nucleotide-binding domain and leucine-rich repeat containing PYD-3 (NLRP3) inflammasome, a multiprotein complex implicated in the pathogenesis of inflammation and chronic inflammatory (63).

\section{Counterregulatory RAAS pathway ACE2/Ang(1-7)/MasR}

In the last 10 years, new counterregulatory RAAS effectors have been identified, including ACE2, angiotensin(1-9), angiotensin(1-7) and MasR.

ACE2 is a transmembrane carboxypeptidase expressed in a variety of tissues including small intestine, testis, adipose tissue, kidney, heart, ovary, and lung (64). ACE2 exerts a protective role by converting proinflammatory Ang I and Ang II into anti-inflammatory Ang(1-9) and Ang(1-7), respectively. Moreover, Ang(1-9) can be converted by ACE into Ang(1-7) that activates intracellular signaling by binding Mas receptor (21). It is noteworthy that ACE2 acts at different steps in RAAS signaling cascade: (i) it mediates the degradation of Ang I, limiting its availability for ACE-mediated generation of Ang II, (ii) it induces the degradation of Ang II and (iii) it promotes the formation of both $\operatorname{Ang}(1-9)$ and Ang(1-7) that exhibit anti-fibrosis and anti-inflammatory actions. Additionally, ACE2, via its C-terminal domain collectrin-homologous, mediates amino acid absorption in small intestine, both by binding neutral amino acid

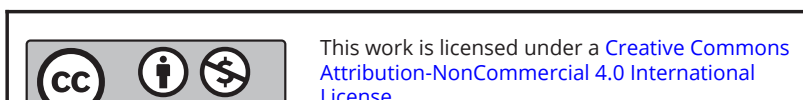
Attribution-NonCommercial 4.0 International 
transporter and increasing its expression (65). Finally, as discussed above, ACE2 is the host receptor for virus spike (S) proteins of the coronaviruses SARS-CoV (14) and SARS-CoV-2 and is a key mediator of COVID-19 infection (17); further, ADAM17 is responsible for the shedding of membrane-bound ACE2 $(47,48)$. The biological and clinical significance of ACE2 ectodomain shedding is yet to be fully characterized and it is still unknown whether increased ACE2 levels in plasma are associated with higher or lower cell membrane-associated ACE2 in tissues and whether circulating ACE2 acts as a decoy, binding SARSCoV-2 and effectively inhibiting cell infection.

Ang(1-9) protective effects are both direct and indirect. In 2011 it was first shown that Ang(1-9) antagonizes Ang II by binding AT2R, a receptor that opposes the sequelae of AT1R signaling (66). Further, Ang(1-9) is converted by ACE into Ang(1-7), the key agonist of the ACE2/Ang(17)/MasR pathway.

Ang(1-7) antagonizes many effects of the Ang II-AT1R axis. It binds MasR, a $\mathrm{G}$ protein-coupled receptor (34), and induces vasodilation, modulates endothelial function, and mediates anti-inflammatory and anti-fibrotic actions. In vessels and in the heart, $\operatorname{Ang}(1-7)$ counteracts Ang II effects by inactivating NOS2/ROS pathway, activating PIK3/Akt/eNOS pathway and therefore enhancing NO production $(67,68)$. Ang $(1-7)$ plays an inhibitory effect on TGFB/SMAD pathway in liver, in skeletal muscle and in renal epithelial cells $(69,70,71)$. In the mouse, exogenous administration of $\operatorname{Ang}(1-7)$ results in antifibrotic cardioprotective effects mediated by decreased TGFB and inflammatory cytokines IL-1B, IL-6 and TNF$A$, and increased collagen degradation by MMP-2 and MMP-9 (72). Indeed, Ang(1-7) decreases inflammatory cytokines, including TNF- $\alpha$ and IL- 6 , and increases ACE2, bradykinin type 2 receptor (BK2R), and IL-10 (73).

ACE2/Ang(1-7)/MasR axis counteracts the Ang II-induced pro-fibrotic effects in the lung both by decreasing the pro-fibrotic miR-21/NLRP3 pathway responsible for lung fibrosis (63) and inhibiting the proapoptotic effect of Ang II in alveolar epithelial cells (74). Moreover, Ang(1-7) directly inhibits TGFB1-Smad signaling pathway in alveolar epithelial cells, a protective effect observed in idiopathic pulmonary fibrosis (75).

\section{Aging- and gender-related modulation of RAAS}

As discussed previously, recent epidemiologic data show that the severity and mortality of COVID-19 infection increase as a function of age, with a steep increase in patients older than 60 years; further, COVID-19 infection is more likely to be severe and lethal in men than women $(2,4,7,8,9)$. These age and gender effects occur independently of comorbidities making aging and male gender independent risk factors for severe COVID19 infection $(10,11,12,13)$. In light of the key role of RAAS in the response to COVID-19 infection, here we will review the effect of aging and gender on key elements of the RAAS cascade with emphasis on ACE2 and on the balance between the Ang II/AT1R and Ang(1-7)/MasR axes.

\section{Aging-related modulation of RAAS}

There is a wealth of data showing that chronic RAAS activation plays a major role in age-associated arterial proinflammation and arterial remodeling (Fig. 3) (76, 77). The increase in Angiotensin II enhances AT1R activation, increases aldosterone production and, via this mediator, mineralcorticoid receptor activation, and it also increases endothelin-1, an agonist with pro-inflammatory and vasoconstrictor actions. Studies in rodents have shown that age-related cardiac and carotid remodeling depend on overexpression of pro-inflammatory effectors of the RAAS pathway, including NADH oxidase (Nox2), MMPs, MCP-1, and TGFB $(78,79,80,81)$. This pro-inflammatory profile was confirmed in the aortic wall of both humans and nonhuman primates $(76,82)$.

The ultimate result of increased RAAS activation and Ang II production is diffuse intima-media thickening, enhanced central arterial stiffening and endothelial dysfunction; these are the key features of arterial aging and the conditions underlying the development of atherosclerosis and heart failure. Several steps in the RAAS signaling exhibit age-related modulation and they are briefly summarized subsequently (Table 1 ).

Studies in aged rats show a decrease both in renal renin formation and secretion, which results in decreased plasma renin concentration (83); in contrast, PRR increase in the thoracic aorta of old mice (84). In agreement with these animal studies, normotensive humans older than 60 years have lower levels of plasma renin than younger adults $(85,86)$.

The local expression of angiotensinogen, the precursor of Ang II, increases in aortic VSMCs of old rats (87). Ang II plasma levels are higher in old than in young rats (76, 88) and also exhibit an age-related increase in murine (84) and human aorta (82).

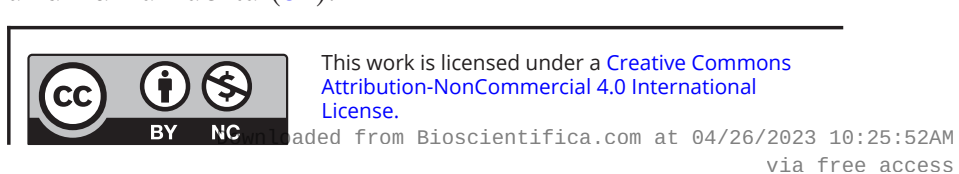




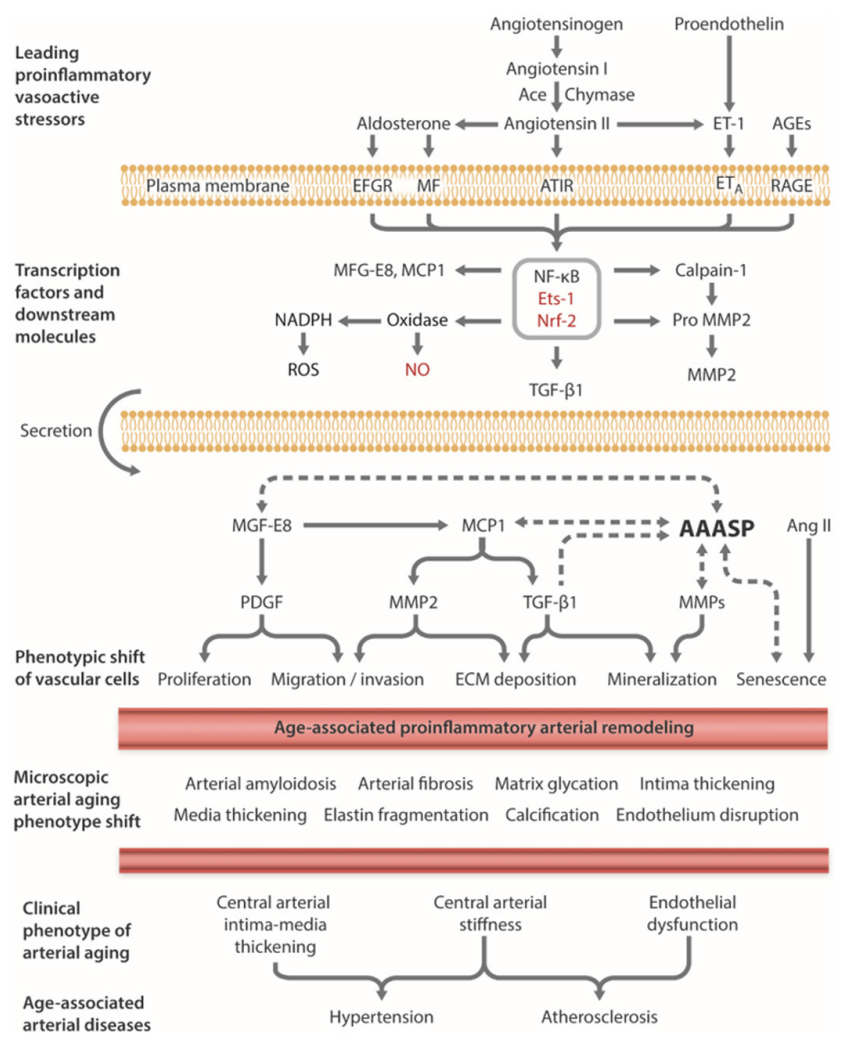

Figure 3

Age-associated arterial remodeling. Ang II promotes arterial remodeling via AT1R, MR, and ET-1/ETA signaling. AGEs recruit inflammatory molecules by interaction with receptor for AGEs (RAGE). NF-kB and Ets-1 are activated within the aging arterial wall, whereas protective factors such as Nrf-2 are reduced. Downstream signaling molecules include MFG-E8, MMPs, calpain-1, MCP-1, and TGF- $\beta 1$. ROS are produced whereas NO bioavailability decreases with advancing age. Old VSMCs produce the AAASP, responsible for the underlying pro-inflammatory state, and exhibit enhanced proliferation, migration, senescence, and extracellular matrix deposition within the aged arterial wall. Disruption of the endothelium, intima-media thickening, arterial amyloidosis, fibrosis, calcification, elastin fracture, and matrix glycoxidative modifications are consequences of the enhanced signaling via these receptor signaling cascades. Ultimately, arteries develop endothelial dysfunction, increased stiffness, and atherosclerosis. Modified from (77). AAASP, age-associated arterial secretory phenotype; ACE, angiotensin converting enzyme; Ang II, angiotensin II; AT1R, angiotensin II type 1 receptor; AGE, advanced glycation end-products; ECM, extracellular matrix; EFGR epidermal growth factor receptor; ET-1, endothelin-1; ETA, endothelin-1 receptor A; Ets-1, v-ets erythroblastosis virus E26 oncogene homolog 1; MCP-1, monocyte chemoattractant protein-1; MFG-E8, milk fat globule epidermal growth factor-8; MMP, matrix metalloprotease; MR, aldosterone/mineralocorticoid receptor; NADPH dihydronicotinamide-adenine dinucleotide phosphate; NF-kB, nuclear factor $\mathrm{k}$ light-chain-enhancer of activated B cells; Nrf-2, NF-E2-related factor 2; NO, nitric oxide; PDGF, platelet-derived growth factor; RAGE, receptor for AGE; ROS, reactive oxygen species; TGF- $\beta 1$, transforming growth factor $\beta 1$; VMSC, vascular smooth muscle cell.

Studies on 3- and 24-month-old rats show that cardiac Ang II levels increase with aging via an ACE-independent pathway mediated by enhanced expression of chymase enzyme (89). Chronic elevation of Ang II induces ROS
Table 1 Age-related modulation of RAAS signaling cascade.

\begin{tabular}{|c|c|c|}
\hline & Age & Reference \\
\hline Renin & Down & $(83,85,86)$ \\
\hline PPR & Up & $(84)$ \\
\hline Angiotensinogen & Up & (87) \\
\hline Ang II & Up & $(76,82,84,88)$ \\
\hline ACE & Up & $(84,91,93)$ \\
\hline ACE2 & Down & $(84,91,93,94,95)$ \\
\hline AT1R & Up & $(84,88,93)$ \\
\hline AT2R & Down & $(84,88)$ \\
\hline Ang(1-7) & Down & $(84,91,93,94,95)$ \\
\hline MasR & Down & (89) \\
\hline
\end{tabular}

$A C E$, angiotensin-converting enzyme; ACE2, angiotensin-converting enzyme 2; Ang, angiotensin II; AT1R, angiotensin II type 1 receptor; AT2R, angiotensin II type 2 receptor; MasR, Mas receptor; PRR, prorenin renin receptor.

production (31), which triggers the release of chymase from mast cells (90) and activates a positive loop that further enhances Ang II production. Higher Ang II level directly contributes to imbalance RAAS by modulating ACE and ACE2 expression. In fact, in vivo infusion of Ang II for 4 weeks increases renal ACE/ACE2 ratio, both by increasing ACE expression and decreasing ACE2 expression (91). High levels of Ang II induce PRR expression resulting in increased renin signaling, thereby amplifying de novo production of Ang II, in a positive feed loop. Moreover, renin and prorenin binding to PRR triggers the activation of MAP kinases ERK1/2 thus leading to downstream activation of pro-fibrotic genes including TGF- $\beta$ and fibronectin $(25,92)$.

Thus, aging-related decrease in prorenin and renin would be expected to decrease Ang II formation; however, the increase in chymase induces the conversion of angiotensinogen into Ang II and Ang II has several effects that include enhanced PRR expression. Under these conditions, in spite of lower renin levels, because of the increase in PRR induced by Ang II, there is increased activation of profibrotic genes and Ang II production.

In the thoracic aorta of 24-month-old compared to 2-month-old mice, ACE, and AT1R increase significantly, whereas expressions of AT2R, ACE2 and Mas receptor decrease (84). These findings on the age-dependence of ACE, AT1R, and ACE2 expression were confirmed in murine kidney when comparing 3- and 24-monthold mice (93). Further, it has been reported that AT1R expression increases and AT2R expression decreases in the old rat heart (88). Postmortem analysis of aortic samples of younger ( $20 \pm 3$ years) and older ( $65 \pm 6$ years) humans who did not succumb to cardiovascular diseases, has shown that older subjects have higher ACE and AT1R levels (82). ACE2 expression was also evaluated in the rat lung at 3,12 , and 24 months and it was found that ACE2

This work is licensed under a Creative Commons Attribution-NonCommercial 4.0 International License. ded from Bioscientifica.com at 04/26/2023 10:25:52AM 
expression in the lung exhibits an age-related decrease (94). A significant reduction in cardiac ACE2 expression leads to lower Ang(1-7) formation. Further, aged rats exhibit lower expression of Mas receptor when compared to younger animals (89).

Recently, the analysis of a large Genotype-Tissue Expression (GTEx) Portal data showed that ACE2 expression decreases during aging in many tissues, including colon, salivary gland, brain and blood vessels, but no change was found in lung (95).

Interestingly, ACE2 is shed into the systemic circulation and its level was evaluated in the plasma of human participants of the InCHIANTI study; a total of 967 participants, 20-90 years old, were analyzed. ACE2 plasma levels exhibited a significant positive association with aging below age 55 and a negative association after age 55 (M AlGhatrif, T Tanaka, AZ Moore, S Bandinelli, EG Lakatta, L Ferrucci, unpublished observations). Further, a study in 23 healthy human subjects has shown an inverse association between ACE2/ACE ratio levels and aging in hematopoietic stem progenitor cells (96).

In summary, most studies show aging-related modulation of RAAS resulting in enhanced proinflammatory ACE/Ang II/ AT1R axis and diminished antagonizing anti-inflammatory response mediated by both AT2R and ACE2/Ang(1-7)/MasR axis.

\section{Gender modulation of RAAS}

There is evidence of an effect of gender on RAAS, however, the mechanisms that underlie gender-related differences are complex. RAAS is modulated both by sex chromosomes, $\mathrm{XX}$ and $\mathrm{XY}$, and sex hormones, estrogen and testosterone (Table 2), with sex hormones production exhibiting a marked variability from birth through senescence, in relation to gender, the menstrual cycle and, eventually, pharmacologic treatment of a variety of conditions including breast and prostate cancer, postmenopausal symptoms, and osteoporosis.

\section{Sex chromosomes}

ACE2 and AT2R genes are the only two RAAS components that are situated on $X$ chromosome $(97,98,99)$. Since females have $\mathrm{XX}$ chromosomes and males have $\mathrm{XY}$ chromosomes is plausible that this difference, per se, independently of hormonal differences, may account for their higher expression in females than in males. Further, the Sry (sex-determining region on the $\mathrm{Y}$ chromosome) gene on the $\mathrm{Y}$ chromosome modulates the activity of RAAS gene promoters and plays a key role in testes development and testosterone production.

Sry gene is a member of the high mobility group (HMG)-box family of DNA-binding proteins. It is located in the nonrecombining region of the $\mathrm{Y}$ chromosome and appears to initiate male sex determination. Sry evolved from the gene Sox3, located on X chromosome, during the process of Y-chromosome formation and is highly conserved in mammals: human and mouse have a single locus, whereas rats all rat strains have 6 Sry loci. Further, Sry3, the seventh Sry locus, is an exclusive additional locus of Spontaneously Hypertensive Rat (SHR) males (100). Its transcripts are expressed in the kidney and brain, two organs involved in blood pressure modulation.

The most relevant insights on the role of sex chromosomes in RAAS pathway regulation comes from studies in two different rodent models the Four Core Genotype (FCG) mouse model and from the Y consomic rat model (for an extensive review, see (101)).

Table 2 Gender-related modulation of RAAS signaling cascade.

\begin{tabular}{|c|c|c|c|c|c|c|}
\hline & \multirow{2}{*}{$\begin{array}{l}\text { Higher levels } \\
\text { observed in }\end{array}$} & \multicolumn{3}{|c|}{ Female } & \multirow{2}{*}{$\begin{array}{l}\text { Male } \\
\text { Androgens }\end{array}$} & \multirow[b]{2}{*}{ Reference } \\
\hline & & $\overline{\mathrm{PM}}$ & POM & ERT & & \\
\hline Renin & Male & Down & Up & Down & Up & $105,108,109$ \\
\hline Agt & Female (PM) & Up & Down & Up & Down & 105,107 \\
\hline Ang II & - & - & Down & Up & Up & $107,111,113,114,116,118,120$ \\
\hline $\mathrm{ACE}$ & Male & Down & Up & Unknown & Up & $105,110,111,112$ \\
\hline ACE2 & Female (PM) & Up & Down & Up & Down & $94,100,103,118,120$ \\
\hline AT1R & Male & Down & Up & Down & No effects & $110,115,118,120$ \\
\hline AT2R & Female & Up & Down & Up & Down & $100,104,111,116,117,118,119$ \\
\hline Ang(1-7) & Female (PM) & Up & Down & Up & Down & $94,100,103,112,118,120$ \\
\hline MasR & Female (PM) & Up & Unknown & Unknown & Down & $100,104,118,119,120$ \\
\hline
\end{tabular}

ACE, angiotensin-converting enzyme; Agt, angiotensinogen; Ang, angiotensin; AT1R, angiotensin II type 1 receptor; AT2R, angiotensin II type 2 receptor; MasR, Mas receptor; PM, premenopause; POM, post menopause; ERT, estrogen replacement therapy (after menopause).

(C) 2021 The authors Published by Bioscientifica Ltd

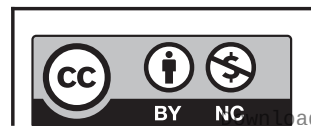

This work is licensed under a Creative Commons Attribution-NonCommercial 4.0 International License.

ded from Bioscientifica.com at 04/26/2023 10:25:52AM 
The FCG mouse model was created to demonstrate that the chromosome complement, which defines gender, is not necessary for the determination of male sexual development (101). The insertion onto an autosome of transgenic Sry and the Sry knockout from the $\mathrm{Y}$ chromosome (producing the $\mathrm{Y}^{-}$chromosome) induce four different genotypes: $\mathrm{XX}$ and $\mathrm{XY}^{\text {sry-, }}$ female mice developing ovaries and producing estrogens; $\mathrm{A}^{\text {Sry } \mathrm{XX} \text { and }}$

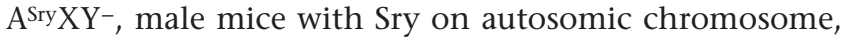
developing testes and producing testosterone. In physiological conditions, when compared animals with the same gonadal type, that is, in a similar hormonal environment ( $\mathrm{XX}$ and $\mathrm{XY}^{\text {Sry-}}$, and $\mathrm{A}^{\text {sry } \mathrm{XX}}$ and $\mathrm{A}^{\text {Sry }} \mathrm{XY}^{-}$), no differences in blood pressure were detected (102). However, after gonadectomy in response to chronic angiotensin II infusion, the blood pressure is greater in $\mathrm{A}^{\text {Sry XY- }}$ and $\mathrm{XY}^{\text {Sry- }}$ (XY genotype) than $\mathrm{A}^{\text {Sry } X X}$ and $\mathrm{XX}$ (XX genotype) (102). In this model, renal ACE2 activity is higher in males ( $\mathrm{A}^{\text {sry } X Y^{-}}$and $\mathrm{A}^{\text {sry } \mathrm{XX}}$ ) (103). However, after gonadectomy enzyme activity increased in female mice (XX and $\mathrm{XY} \mathrm{Yry}^{\text {sry }}$, although no differences are observed in the cardiac muscle or lung in mice or rats (103). Since ACE2 gene is located on the $\mathrm{X}$ chromosome, its expression and activity would be expected to correlate with the number of $\mathrm{X}$ chromosomes present. Therefore, the higher ACE2 renal activity in males suggests that it is hormonaldependent rather than chromosome-dependent (103).

The Y consomic rat model was obtained from two different strains: the normotensive Wystar Kyoto (WKY) rat and the Spontaneous Hypertensive Rat (SHR). The male resulting progeny has a 'normotensive' $\mathrm{Y}$ chromosome or the 'hypertensive' one, derived from WKY and SHR, respectively. Since all the animals have a normal sexual development, it would be difficult account the testosterone's effects by its own nature, while chromosome effect is easy to evaluate. The $\mathrm{Y}$ consomic rat model demonstrated that the $\mathrm{Y}$ chromosome can regulate arterial pressure via the Sry gene family, specifically, Sry3. Intriguingly, Sry3 is not present in WKY normotensive rat but it is present in SHR. The in vitro overexpression of rat Sry3, as well as the co-transfection of human SRY expression constructs in vitro in Chinese Hamster Ovary cells (CHO), positively modulates angiotensinogen, renin, and ACE promoter activity, thus shifting RAAS toward vasoconstrictive responses, while the promoters of ACE2, AT2R, and MasR are downregulated (100, 104, 105). In WKY rats, Sry3 overexpression in vivo increases ACE expression by $40 \%$ and consequently Ang II concentration (101).
However, ACE2 and AT2R expressions are is also sensitive to sex hormones as it will be discussed in the next section.

\section{Sex hormones}

Accumulating evidence suggests that different components of the RAAS pathway are modulated by sex hormones (106).

Angiotensinogen promoter contains an estrogenresponsive element: in fact, angiotensinogen circulating levels are higher in pre-menopausal women than in postmenopausal women and men, and estrogen replacement therapy can rescue angiotensinogen secretion in post-menopausal women (107). Conversely, plasma renin is higher in males than in females, an observation made in humans, rats, and mice $(108,109)$. Post-menopausal women without substitutive therapy exhibit higher renin levels than premenopausal women and postmenopausal women on hormonal replacement therapy (109). Further, plasma renin activity increases after ovariectomy and testosterone treatment in female rats and it decreases in male rats after castration (109).

ACE activity is downregulated by estrogens and upregulated by androgens. In post-pubertal children and in young healthy adults, ACE activity is lower in females than in males. After menopause, women have comparable ACE activity to age-matched men; estrogens replacement gives inconsistent results, with no change, increased or decreased ACE activity (110). However, a decrease in ACE activity in response to estrogen replacement therapy occurs in female rats and postmenopausal female monkeys $(111,112)$.

Plasma Ang II levels exhibit no gender difference prior to menopause. After menopause, plasma Ang II levels are upregulated in response to estrogen replacement therapy in women (113), in postmenopausal monkeys (111), and ovariectomized rats (114).

AT1R expression is downregulated by estrogens in several tissues, both in rats and beagles (110). A similar observation has been made in vascular smooth muscle cells isolated from rats (110). No effect of androgens on AT1R has been reported (115).

Regarding the effect of gonadal hormones on counterregulatory RAAS components there are limited data available. AT2R expression is upregulated by estrogens in adrenal and renal tissues, both in male and female rats, and downregulated by testosterone in mice and rat aorta

This work is licensed under a Creative Commons Attribution-NonCommercial 4.0 International License. 
(116). AT2R gene expression and binding are upregulated in female mice with hormonal replacement therapy (117).

Several studies have examined the effect of gender and estrogens on ACE2. Renal ACE2 expression and activity, as well as MasR gene expression, are higher in female than in male rats, and $\operatorname{Ang}(1-7)$ is positively modulated by estrogens in female rats (118). In agreement with these observations Ang(1-7) plasma levels are low in males and in females after ovariectomy, whereas the administration of estrogens rescues ACE2 and, consequently, circulating Ang(1-7) (110). Moreover, Ang(1-7) plasma levels are higher in premenopausal than post-menopausal women and the ex vivo administration of estrogens to atrial myocardial tissue isolated from old men decreased ACE expression and increased expression levels of ACE2, AT2R, and MasR (119).

Interestingly, plasma ACE2 levels in the participants in the InCHIANTI study demonstrated no effect of gender on ACE2 plasma levels (M AlGhatrif, T Tanaka, AZ Moore, S Bandinelli, EG Lakatta, L Ferrucci, unpublished observations, work submitted for publication).

In summary, ACE/Ang II/AT1R axis appears to be more active in males and ACE2/Ang(1-7)/MasR, and AT2R pathways are more active in females $(118,120)$. Estrogens shift the balance of the RAAS toward ACE2/Ang(1-7)/ MasR axis from the ACE/Ang II/AT1R axis; in contrast, testosterone has the opposite effect and enhances ACE/ Ang II/AT1R effects.

\section{Conclusions}

In this review, we have examined the effect of aging and gender on RAAS and on the potential role of RAAS in determining the severity and poor outcome of SARSCoV-2 infection.

ACE2 appears to play a pivotal role because it is the SARS-CoV-2 host receptor and, following virus binding, it is internalized; this event is a key initial step in viral infection and intracellular viral replication. Further, once ACE2 is internalized, it can no longer convert Ang II into Ang(1-7), likely enhancing the pro-inflammatory Ang II/ AT1R axis at the expense of the anti-inflammatory Ang(17)/MasR axis. Indeed, it is now established that a severe pro-inflammatory cytokine storm underlies the severe multiorgan failure and poor outcome frequently observed in patients with COVID-19 disease.

The events that lead to SARS-CoV-2 infection and modulate the inflammatory response remain to be fully elucidated. It is plausible that high ACE2 expression in young people and females plays a role in the high incidence of COVID-19 infection; however, high ACE2 would also be expected to shift the pro-inflammatory Ang II/AT1R axis and anti-inflammatory Ang(1-7)/MasR axis toward the anti-inflammatory response and ultimately will be more likely to cause a COVID-19 disease with no or minimal symptoms. In contrast, advanced age and male gender are independent risk factors for more severe infection and worse outcome in patients with COVID-19 disease. The mechanism/s for these highly relevant clinical findings have not been fully elucidated; however, advanced age and male gender are associated with diminished ACE2 expression and a balance between pro-inflammatory Ang II/AT1R axis and anti-inflammatory Ang(1-7)/MasR axis shifted toward an enhanced inflammatory response and more severe disease.

It is noteworthy that after menopause gender differences remain in the severity of COVID-19 disease and poor outcome. These differences persist and need to be reconciled with the results of animal and human studies suggesting a shift toward a pro-inflammatory condition of the balance between the pro-inflammatory Ang II/AT1R axis and anti-inflammatory Ang(1-7)/MasR axis after menopause. Unfortunately, no studies have adequately compared ACE/Ang II/AT1R axis and ACE2/ Ang(1-7)/MasR axis in age-matched males and postmenopausal females neither in humans nor in other species; therefore, it is possible that some gender-related differences in RAAS may persist. Finally, it is possible that after menopause gender may no longer represent an independent risk factor for the development of severe COVID-19 infection and poor outcome and that a higher prevalence of comorbidities may be the key factor responsible for the increased risk of elderly males.

Pharmacological modulation of ACE2 expression theoretically contributes to the predisposition for the COVID-19 disease. This notion has driven an earlier controversy around whether the increased ACE2 expression associated with the use of angiotensin converting enzyme inhibitors (ACEi) and angiotensin-2 receptor blockers (ARB), increases COVID-19 risk (121, 122). However, so far, observational data has shown no difference in COVID-19 occurrence or severity among those on these medications and those who are not (123).

Some additional aspects of ACE2 biology are relevant to the present study. Recently, electrical vagal nerve stimulation (VNS) has been proposed for COVID19 treatment. Acetylcholine (ACh), the principal neurotransmitter of the vagus nerve, inhibits the production of inflammatory cytokines and macrophage-TNF

\section{This work is licensed under a Creative Commons Attribution-NonCommercial 4.0 International} License. 
release specifically via $\alpha 7$ nicotinic $A C h$ receptors $(\alpha 7 \mathrm{nAChR})$ mediating the cholinergic anti-inflammatory pathway $(124,125,126)$. Moreover, it has been reported that exposure to nicotine causes epithelial cells to increase ACE2 levels, via $\alpha 7 n$ AChR $(127,128)$. Further experimental investigations and ongoing clinical trials will determine the potential therapeutic use of VNS for SARS-CoV-2.

While still limited, more data has become available on the epidemiological changes of ACE2 levels and their correlation epidemiological pattern of COVID-19. Earlier epidemiological data, which were predominantly from sick and hospitalized patient, have shown a greater COVID-19 impact on older individuals (page accessed on December 3, 2020: https://www.cdc.gov/bloodpressure/ facts.htm?CDC_AA_refVal=https $\% 3 \mathrm{~A} \% 2 \mathrm{~F} \% 2 \mathrm{Fwww} . \mathrm{cdc}$. gov $\% 2$ Fdhdsp $\% 2$ Fdata_statistics $\% 2$ Ffact_sheets $\% 2$ Ffs_ bloodpressure.htm). However, with increase community testing of mild-to-moderate cases, it became apparent that younger adults have the greatest incidence, followed by older adults, while children have the lowest rates of occurrence (129).

Finally, although the relation between circulating and tissues-associated ACE2 is still unclear, it is noteworthy that the InCHIANTI study showed that ACE2 plasma levels exhibited a significant positive association with aging before the age 55 and a negative association after age 55 (M AlGhatrif, T Tanaka, AZ Moore, S Bandinelli, EG Lakatta, L Ferrucci, unpublished observations). In conclusion, our present knowledge of RAAS and COVID19 infection leads us to formulate plausible experimental hypotheses but much remains to be done in order to establish the role of RAAS in COVID-19 infection, characterize the mechanisms leading to more severe infections and worse outcome in elderly patients and in males, and establish the role, if any, of drugs such as ACE inhibitors and angiotensin receptor blockers that modulate RAAS in ameliorating or worsening the severity of COVID-19 infection.

\section{Declaration of interest}

Maurizio C Capogrossi is a Senior Editor of Vascular Biology. Maurizio C Capogrossi was not involved in the review or editorial process for this paper, on which he is listed as an author. The other authors have nothing to disclose.

\section{Funding}

This work was supported by the Intramural Research Program of the $\mathrm{NIH}$, National Institute on Aging.

\section{Author contribution statement}

$L M, M C F$, and M C C conceived the idea for the article. L M, M C F, and $M$ $C C$ performed the literature search and drafted the review. $L M, M C F, M$ A, E G L, and M C C critically revised the work.

\section{References}

1 Guo T, Fan Y, Chen M, Wu X, Zhang L, He T, Wang H, Wan J, Wang X \& Lu Z. Cardiovascular implications of fatal outcomes of patients with coronavirus disease 2019 (COVID-19). JAMA Cardiology 20205 811-818. (https://doi.org/10.1001/jamacardio.2020.1017)

2 Zhou F, Yu T, Du R, Fan G, Liu Y, Liu Z, Xiang J, Wang Y, Song B, $\mathrm{Gu} \mathrm{X}$, et al. Clinical course and risk factors for mortality of adult inpatients with COVID-19 in Wuhan, China: a retrospective cohort study. Lancet 2020395 1054-1062. (https://doi.org/10.1016/S01406736(20)30566-3)

3 Zhou P, Yang XL, Wang XG, Hu B, Zhang L, Zhang W, Si HR, Zhu Y, Li B, Huang CL, et al. A pneumonia outbreak associated with a new coronavirus of probable bat origin. Nature 2020579 270-273. (https://doi.org/10.1038/s41586-020-2012-7)

4 Huang C, Wang Y, Li X, Ren L, Zhao J, Hu Y, Zhang L, Fan G, Xu J, $\mathrm{Gu}$ X, et al. Clinical features of patients infected with 2019 novel coronavirus in Wuhan, China. Lancet 2020395 497-506. (https:// doi.org/10.1016/S0140-6736(20)30183-5)

5 Berry M, Gamieldien J \& Fielding BC. Identification of new respiratory viruses in the new millennium. Viruses 20157 996-1019. (https://doi.org/10.3390/v7030996)

6 Mohd HA, Al-Tawfiq JA \& Memish ZA. Middle East respiratory syndrome coronavirus (MERS-CoV) origin and animal reservoir. Virology Journal 201613 87. (https://doi.org/10.1186/s12985-016-0544-0)

7 Wortham JM, Lee JT, Althomsons S, Latash J, Davidson A, Guerra K, Murray K, McGibbon E, Pichardo C, Toro B et al. Characteristics of Persons Who Died with COVID-19 - United States, February 12-May 18, 2020. Morbidity and Mortality Report 202069 923-929. (https:// doi.org/10.15585/mmwr.mm6928e1)

8 Wang D, Hu B, Hu C, Zhu F, Liu X, Zhang J, Wang B, Xiang H, Cheng Z, Xiong Y, et al. Clinical characteristics of 138 hospitalized patients with 2019 novel coronavirus-infected pneumonia in Wuhan, China. JAMA 2020323 1061-1069. (https://doi. org/10.1001/jama.2020.1585)

9 Chen N, Zhou M, Dong X, Qu J, Gong F, Han Y, Qiu Y, Wang J, Liu Y, Wei Y, et al. Epidemiological and clinical characteristics of 99 cases of 2019 novel coronavirus pneumonia in Wuhan, China: a descriptive study. Lancet 2020395 507-513. (https://doi.org/10.1016/S01406736(20)30211-7)

10 Scully EP, Haverfield J, Ursin RL, Tannenbaum C \& Klein SL. Considering how biological sex impacts immune responses and COVID-19 outcomes. Nature Reviews: Immunology 202020 442-447. (https://doi.org/10.1038/s41577-020-0348-8)

11 Palaiodimos L, Kokkinidis DG, Li W, Karamanis D, Ognibene J, Arora S, Southern WN \& Mantzoros CS. Severe obesity, increasing age and male sex are independently associated with worse in-hospital outcomes, and higher in-hospital mortality, in a cohort of patients with COVID-19 in the Bronx, New York. Metabolism: Clinical and Experimental 2020108 154262. (https://doi.org/10.1016/j. metabol.2020.154262)

12 Liu D, Cui P, Zeng S, Wang S, Feng X, Xu S, Li R, Gao Y, Yu R, Wang Y, et al. Risk factors for developing into critical COVID-19 patients in Wuhan, China: a multicenter, retrospective, cohort study. EClinicalmedicine 202025 100471. (https://doi.org/10.1016/j. eclinm.2020.100471)

13 Groban L, Wang H, Sun X, Ahmad S \& Ferrario CM. Is sex a determinant of COVID-19 infection? Truth or myth? Current

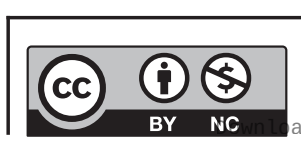

This work is licensed under a Creative Commons Attribution-NonCommercial 4.0 International License. 
Hypertension Reports 202022 62. (https://doi.org/10.1007/s11906020-01073-x)

14 Li W, Moore MJ, Vasilieva N, Sui J, Wong SK, Berne MA, Somasundaran M, Sullivan JL, Luzuriaga K, Greenough TC, et al. Angiotensin-converting enzyme 2 is a functional receptor for the SARS coronavirus. Nature 2003426 450-454. (https://doi. org/10.1038/nature02145)

15 Imai Y, Kuba K, Rao S, Huan Y, Guo F, Guan B, Yang P, Sarao R, Wada T, Leong-Poi $\mathrm{H}$, et al. Angiotensin-converting enzyme 2 protects from severe acute lung failure. Nature 2005436 112-116. (https://doi.org/10.1038/nature03712)

16 Kuba K, Imai Y, Rao S, Gao H, Guo F, Guan B, Huan Y, Yang P, Zhang Y, Deng W, et al. A crucial role of angiotensin converting enzyme 2 (ACE2) in SARS coronavirus-induced lung injury. Nature Medicine 200511 875-879. (https://doi.org/10.1038/nm1267)

17 Hoffmann M, Kleine-Weber H, Schroeder S, Kruger N, Herrler T, Erichsen S, Schiergens TS, Herrler G, Wu NH, Nitsche A, et al. SARSCoV-2 cell entry depends on ACE2 and TMPRSS 2 and is blocked by a clinically proven protease inhibitor. Cell 2020181 271.e8-280.e8. (https://doi.org/10.1016/j.cell.2020.02.052)

18 Dijkman R, Jebbink MF, Deijs M, Milewska A, Pyrc K, Buelow E, van der Bijl A \& van der Hoek L. Replication-dependent downregulation of cellular angiotensin-converting enzyme 2 protein expression by human coronavirus NL63. Journal of General Virology 201293 1924-1929. (https://doi.org/10.1099/vir.0.043919-0)

19 Wrapp D, Wang N, Corbett KS, Goldsmith JA, Hsieh CL, Abiona O Graham BS \& McLellan JS. Cryo-EM structure of the 2019-nCoV spike in the prefusion conformation. Science 2020367 1260-1263. (https://doi.org/10.1126/science.abb2507)

20 Yan R, Zhang Y, Li Y, Xia L, Guo Y \& Zhou Q. Structural basis for the recognition of SARS-CoV-2 by full-length human ACE2. Science 2020 367 1444-1448. (https://doi.org/10.1126/science.abb2762)

21 Bader M. ACE2, angiotensin-(1-7), and Mas: the other side of the coin. Pflugers Archiv 2013465 79-85.

22 Heurich A, Hofmann-Winkler H, Gierer S, Liepold T, Jahn O \& Pöhlmann S. TMPRSS2 and ADAM17 cleave ACE2 differentially and only proteolysis by TMPRSS2 augments entry driven by the severe acute respiratory syndrome coronavirus spike protein. Journal of Virology 201488 1293-1307. (https://doi.org/10.1128/JVI.02202-13)

23 Kurtz A. Control of renin synthesis and secretion. American Journal of Hypertension 201225 839-847. (https://doi.org/10.1038/ajh.2011.246)

24 Ichihara A, Itoh H \& Inagami T. Critical roles of (pro)renin receptor-bound prorenin in diabetes and hypertension: sallies into therapeutic approach. Journal of the American Society of Hypertension 20082 15-19. (https://doi.org/10.1016/j.jash.2007.08.001)

25 Nguyen G. Renin, (pro)renin and receptor: an update. Clinical Science 2011120 169-178.

26 Karnik SS, Unal H, Kemp JR, Tirupula KC, Eguchi S, Vanderheyden PM \& Thomas WG. International Union of Basic and Clinical Pharmacology. XCIX. Angiotensin receptors: interpreters of pathophysiological angiotensinergic stimuli (corrected) Pharmacological Reviews 201567 754-819. (https://doi.org/10.1124/ pr.114.010454)

27 Arlene Wolny J-PC, Rein J, Mory P, Vogt P, Turino M, Kiowski W \& Fischli W. Functional and biochemical analysis of angiotensin II-forming pathways in the human heart. Circulation Research 1997 80 219-227.

28 Touyz RM \& Schiffrin EL. Angiotensin II regulates vascular smooth muscle cell $\mathrm{pH}$, contraction, and growth via tyrosine kinasedependent signaling pathways. Hypertension $199730222-229$. (https://doi.org/10.1161/01.hyp.30.2.222)

29 Bkaily G, El-Bizri N, Nader M, Hazzouri KM, Riopel J, Jacques D, Regoli D, D'Orleans-Juste P, Gobeil F \& Avedanian L. Angiotensin II induced increase in frequency of cytosolic and nuclear calcium waves of heart cells via activation of AT1 and AT2 receptors. Peptides 200526 1418-1426. (https://doi.org/10.1016/j.peptides.2005.03.051)
30 Williams GH. Aldosterone biosynthesis, regulation, and classical mechanism of action. Heart Failure Reviews 200510 7-13. (https:// doi.org/10.1007/s10741-005-2343-3)

31 Griendling KK, Minieri CA, Ollerenshaw JD \& Alexander RW. Angiotensin II stimulates NADH and NADPH oxidase activity in cultured vascular smooth muscle cells. Circulation Research 199474 1141-1148.

32 Padia SH \& Carey RM. AT2 receptors: beneficial counter-regulatory role in cardiovascular and renal function. Pflugers Archiv 2013465 99-110. (https://doi.org/10.1007/s00424-012-1146-3)

33 Siragy HM \& Carey RM. The subtype 2 (AT2) angiotensin receptor mediates renal production of nitric oxide in conscious rats. Journal of Clinical Investigation 1997100 264-269. (https://doi.org/10.1172/ JCI119531)

34 Santos RA, Simoes e Silva AC, Maric C, Silva DM, Machado RP, de Buhr I, Heringer-Walther S, Pinheiro SV, Lopes MT, Bader M, et al. Angiotensin-(1-7) is an endogenous ligand for the $G$ protein-coupled receptor Mas. PNAS 2003100 8258-8263. (https://doi.org/10.1073/ pnas. 1432869100

35 Montezano AC, Cat AND, Rios FJ \& Touyz RM. Angiotensin II and vascular injury. Current Hypertension Reports 201416 431. (https:// doi.org/10.1007/s11906-014-0431-2)

36 Dimmeler S, Rippmann V, Weiland U, Haendeler J \& Zeiher AM. Angiotensin II induces apoptosis of human endothelial cells protective effect of nitric oxide. Circulation Research $1997 \mathbf{8 1}$ 970-976.

37 Suzuki E, Nishimatsu H, Satonaka H, Walsh K, Goto A, Omata M, Fujita T, Nagai R \& Hirata Y. Angiotensin II induces myocyte enhancer factor 2- and calcineurin/nuclear factor of activated T cell-dependent transcriptional activation in vascular myocytes. Circulation Research 200290 1004-1011. (https://doi.org/10.1161/01. res.0000017629.70769.cc)

38 Molkentin JD, Lu JR, Antos CL, Markham B, Richardson J, Robbins J, Grant SR \& Olson EN. A calcineurin-dependent transcriptional pathway for cardiac hypertrophy. Cell 199893 215-228. (https://doi. org/10.1016/s0092-8674(00)81573-1)

39 Sadoshima I. Molecular characterization of angiotensin II-induced hypertrophy of cardiac myocytes and hyperplasia of cardiac fibroblasts critical role of the AT1 receptor subtype. Circulation Research 199373 413-423.

40 Geisterfer AA, Peach MJ \& Owens GK. Angiotensin II induces hypertrophy, not hyperplasia, of cultured rat aortic smooth muscle cells. Circulation Research 198862 749-756.

41 Inagami T \& Eguchi S. Angiotensin II-mediated vascular smooth muscle cell growth signaling. Brazilian Journal of Medical and Biological Research 200033 619-624. (https://doi.org/10.1590/s0100 $879 \times 2000000600002)$

42 Saward L \& Zahradka P. Angiotensin II activates phosphatidylinositol 3-kinase in vascular smooth muscle cells. Circulation Research 1997 81 249-257. (https://doi.org/10.1161/01.res.81.2.249)

43 Pan J, Fukuda K, Kodama H, Maniko S, Takahashi T, Sano M, Hori S \& Ogawa S. Role of angiotensin II in activation of the JAK/ STAT pathway induced by acute pressure overload in the rat heart. Circulation Research 199781 611-617.

44 Higuchi S, Ohtsu H, Suzuki H, Shirai H, Frank GD \& Eguchi S. Angiotensin II signal transduction through the AT1 receptor: novel insights into mechanisms and pathophysiology. Clinical Science 2007 112 417-428. (https://doi.org/10.1042/CS20060342)

45 Saito Y \& Berk BC. Transactivation: a novel signaling pathway from angiotensin II to tyrosine kinase receptors. Journal of Molecular and Cellular Cardiology 200133 3-7. (https://doi.org/10.1006/ jmcc.2000.1272)

46 Ohtsu H, Dempsey PJ, Frank GD, Brailoiu E, Higuchi S, Suzuki H, Nakashima H, Eguchi K \& Eguchi S. ADAM17 mediates epidermal growth factor receptor transactivation and vascular smooth muscle cell hypertrophy induced by angiotensin II. Arteriosclerosis, 
Thrombosis, and Vascular Biology 200626 e133-e137. (https://doi org/10.1161/01.ATV.0000236203.90331.d0)

47 Lambert DW, Yarski M, Warner FJ, Thornhill P, Parkin ET, Smith AI, Hooper NM \& Turner AJ. Tumor necrosis factor-alpha convertase (ADAM17) mediates regulated ectodomain shedding of the severeacute respiratory syndrome-coronavirus (SARS-CoV) receptor, angiotensin-converting enzyme-2 (ACE2). Journal of Biological Chemistry 2005280 30113-30119. (https://doi.org/10.1074/jbc. M505111200)

48 Patel VB, Clarke N, Wang Z, Fan D, Parajuli N, Basu R, Putko B, Kassiri Z, Turner AJ \& Oudit GY. Angiotensin II induced proteolytic cleavage of myocardial ACE2 is mediated by TACE/ADAM-17: a positive feedback mechanism in the RAS. Journal of Molecular and Cellular Cardiology 201466 167-176. (https://doi.org/10.1016/j. yjmcc.2013.11.017)

49 Vaughan DE, Lazos SA \& Tong K. Angiotensin II regulates the expression of plasminogen activator inhibitor-1 in cultured endothelial cells. A potential link between the renin-angiotensin system and thrombosis. Journal of Clinical Investigation 199595 995-1001.

50 Wang W, Huang XR, Canlas E, Oka K, Truong LD, Deng C, Bhowmick NA, Ju W, Bottinger EP \& Lan HY. Essential role of Smad3 in angiotensin II-induced vascular fibrosis. Circulation Research 2006 98 1032-1039. (https://doi.org/10.1161/01.RES.0000218782.52610. dc)

51 Rodriguez-Vita J, Sanchez-Lopez E, Esteban V, Ruperez M, Egido J \& Ruiz-Ortega M. Angiotensin II activates the Smad pathway in vascular smooth muscle cells by a transforming growth factor-betaindependent mechanism. Circulation 2005111 2509-2517. (https:// doi.org/10.1161/01.CIR.0000165133.84978.E2)

52 Ruperez M, Lorenzo O, Blanco-Colio LM, Esteban V, Egido J \& Ruiz-Ortega M. Connective tissue growth factor is a mediator of angiotensin II-induced fibrosis. Circulation 2003108 1499-1505. (https://doi.org/10.1161/01.CIR.0000089129.51288.BA)

53 Zhang GY, Li X, Yi CG, Pan H, He GD, Yu Q, Jiang LF, Xu WH, Li ZJ, Ding J, et al. Angiotensin II activates connective tissue growth factor and induces extracellular matrix changes involving Smad/activation and p38 mitogen-activated protein kinase signalling pathways in human dermal fibroblasts. Experimental Dermatology 200918 947-953. (https://doi.org/10.1111/j.1600-0625.2009.00880.x)

54 Kamat NV, Thabet SR, Xiao L, Saleh MA, Kirabo A, Madhur MS, Delpire E, Harrison DG \& McDonough AA. Renal transporter activation during angiotensin-II hypertension is blunted in interferon-gamma-/- and interleukin-17A-/- mice. Hypertension 201565 569-576. (https://doi.org/10.1161/ HYPERTENSIONAHA.114.04975)

55 Peng H, Sarwar Z, Yang XP, Peterson EL, Xu J, Janic B, Rhaleb N, Carretero OA \& Rhaleb NE. Profibrotic role for interleukin-4 in cardiac remodeling and dysfunction. Hypertension 201566 582-589. (https://doi.org/10.1161/HYPERTENSIONAHA.115.05627)

56 Guo F, Chen XL, Wang F, Liang X, Sun YX \& Wang YJ. Role of angiotensin II Type 1 receptor in angiotensin II-induced cytokine production in macrophages. Journal of Interferon and Cytokine Research 201131 351-361. (https://doi.org/10.1089/jir.2010.0073)

57 O'Leary R, Penrose H, Miyata K \& Satou R. Macrophage-derived IL-6 contributes to ANG II-mediated angiotensinogen stimulation in renal proximal tubular cells. American Journal of Physiology: Renal Physiology 2016310 F1000-F1007. (https://doi.org/10.1152/ ajprenal.00482.2015)

58 Zhang L, Du J, Hu Z, Han G, Delafontaine P, Garcia G \& Mitch WE. IL-6 and serum amyloid A synergy mediates angiotensin II-induced muscle wasting. Journal of the American Society of Nephrology 200920 604-612. (https://doi.org/10.1681/ASN.2008060628)

59 Senchenkova EY, Russell J, Yildirim A, Granger DN \& Gavins FNE. Novel role of T cells and IL-6 (interleukin-6) in angiotensin
II-induced microvascular dysfunction. Hypertension 201973 829-838. (https://doi.org/10.1161/HYPERTENSIONAHA.118.12286)

60 Uhal BD, Li X, Piasecki CC \& Molina-Molina M. Angiotensin signalling in pulmonary fibrosis. International Journal of Biochemistry and Cell Biology 201244 465-468. (https://doi.org/10.1016/j. biocel.2011.11.019)

61 Wang J, Chen L, Chen B, Meliton A, Liu SQ, Shi Y, Liu T, Deb DK, Solway J \& Li YC. Chronic activation of the renin-angiotensin system induces lung fibrosis. Scientific Reports 20155 15561. (https://doi. org/10.1038/srep15561)

62 Parra ER, Ruppert AD \& Capelozzi VL. Angiotensin II type 1 and 2 receptors and lymphatic vessels modulate lung remodeling and fibrosis in systemic sclerosis and idiopathic pulmonary fibrosis. Clinics 201469 47-54. (https://doi.org/10.6061/clinics/2014(01)07)

63 Sun NN, Yu CH, Pan MX, Zhang Y, Zheng BJ, Yang QJ, et al. Mir-21 mediates the inhibitory effect of Ang (1-7) on AngII-induced NLRP3 inflammasome activation by targeting Spry1 in lung fibroblasts. Scientific Reports $2017 \mathbf{7} 14369$.

64 Chen L, Li X, Chen M, Feng Y \& Xiong C. The ACE2 expression in human heart indicates new potential mechanism of heart injury among patients infected with SARS-CoV-2. Cardiovascular Research 2020116 1097-1100. (https://doi.org/10.1093/cvr/cvaa078)

65 Singer D, Camargo SM, Ramadan T, Schafer M, Mariotta L, Herzog B, Huggel K, Wolfer D, Werner S, Penninger JM, et al. Defective intestinal amino acid absorption in Ace2 null mice. American Journal of Physiology: Gastrointestinal and Liver Physiology $20123 \mathbf{3 0 3}$ G686-G695. (https://doi.org/10.1152/ajpgi.00140.2012)

66 Flores-Munoz M, Smith NJ, Haggerty C, Milligan G \& Nicklin SA. Angiotensin1-9 antagonises pro-hypertrophic signalling in cardiomyocytes via the angiotensin type 2 receptor. Journal of Physiology 2011589 939-951. (https://doi.org/10.1113/ jphysiol.2010.203075)

67 Xiao X, Zhang C, Ma X, Miao H, Wang J, Liu L, Chen S, Zeng R, Chen Y \& Bihl JC. Angiotensin-(1-7) counteracts angiotensin II-induced dysfunction in cerebral endothelial cells via modulating Nox2/ROS and PI3K/NO pathways. Experimental Cell Research 2015 336 58-65. (https://doi.org/10.1016/j.yexcr.2015.06.010)

68 Zhang F, Tang H, Sun S, Luo Y, Ren X, Chen A, Xu Y, Li P \& Han Y. Angiotensin-(1-7) induced vascular relaxation in spontaneously hypertensive rats. Nitric Oxide: Biology and Chemistry 201988 1-9. (https://doi.org/10.1016/j.niox.2019.03.007)

69 Cai SM, Yang RQ, Li Y, Ning ZW, Zhang LL, Zhou GS, Luo W, Li DH, Chen Y, Pan MX, et al. Angiotensin-(1-7) improves liver fibrosis by regulating the NLRP3 inflammasome via redox balance modulation. Antioxidants and Redox Signaling 201624 795-812. (https://doi. org/10.1089/ars.2015.6498)

70 Acuna MJ, Pessina P, Olguin H, Cabrera D, Vio CP, Bader M, MuñozCanoves P, Santos RA, Cabello-Verrugio C \& Brandan E. Restoration of muscle strength in dystrophic muscle by angiotensin-1-7 through inhibition of TGF-beta signalling. Human Molecular Genetics 201423 1237-1249. (https://doi.org/10.1093/hmg/ddt514)

71 Chou CH, Chuang LY, Lu CY \& Guh JY. Interaction between TGFbeta and ACE2-Ang-(1-7)-Mas pathway in high glucose-cultured NRK-52E cells. Molecular and Cellular Endocrinology 2013366 21-30. (https://doi.org/10.1016/j.mce.2012.11.004)

72 Li Y, Wu J, He Q, Shou Z, Zhang P, Pen W, Zhu Y \& Chen J. Angiotensin (1-7) prevent heart dysfunction and left ventricular remodeling caused by renal dysfunction in 5/6 nephrectomy mice. Hypertension Research 200932 369-374. (https://doi.org/10.1038/ hr.2009.25)

73 Qi Y, Shenoy V, Wong F, Li H, Afzal A, Mocco J, Sumners C, Raizada MK \& Katovich MJ. Lentivirus-mediated overexpression of angiotensin-(1-7) attenuated ischaemia-induced cardiac pathophysiology. Experimental Physiology 201196 863-874. (https:// doi.org/10.1113/expphysiol.2011.056994) (c) 2021 The authors Published by Bioscientifica Ltd

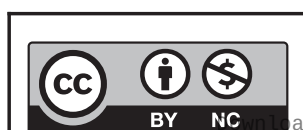

This work is licensed under a Creative Commons Attribution-NonCommercial 4.0 International License. ded from Bioscientifica.com at 04/26/2023 10:25:52AM 
74 Uhal BD, Li X, Xue A, Gao X \& Abdul-Hafez A. Regulation of alveolar epithelial cell survival by the ACE-2/angiotensin 1-7/Mas axis. American Journal of Physiology: Lung Cellular and Molecular Physiology 2011301 L269-L274. (https://doi.org/10.1152/ajplung.00222.2010)

75 Shao M, Wen ZB, Yang HH, Zhang CY, Xiong JB, Guan XX, Zhong WJ, Jiang HL, Sun CC, Luo XQ, et al. Exogenous angiotensin (1-7) directly inhibits epithelial-mesenchymal transformation induced by transforming growth factor-beta1 in alveolar epithelial cells. Biomedicine and Pharmacotherapy 2019117 109193. (https://doi. org/10.1016/j.biopha.2019.109193)

76 Wang M, Takagi G, Asai K, Resuello RG, Natividad FF, Vatner DE, Vatner SF \& Lakatta EG. Aging increases aortic MMP-2 activity and angiotensin II in nonhuman primates. Hypertension $2003 \mathbf{4 1}$ 1308-1316. (https://doi.org/10.1161/01.HYP.0000073843.56046.45)

77 Wang M, Jiang L, Monticone RE \& Lakatta EG. Proinflammation: the key to arterial aging. Trends in Endocrinology and Metabolism 201425 72-79. (https://doi.org/10.1016/j.tem.2013.10.002)

78 Wang M, Zhang J, Walker SJ, Dworakowski R, Lakatta EG \& Shah AM. Involvement of NADPH oxidase in age-associated cardiac remodeling. Journal of Molecular and Cellular Cardiology 201048 765-772. (https://doi.org/10.1016/j.yjmcc.2010.01.006)

79 Wang M, Zhang J, Spinetti G, Jiang LQ, Monticone R, Zhao D, Cheng L, Krawczyk M, Talan M, Pintus G, et al. Angiotensin II activates matrix metalloproteinase Type II and mimics age-associated carotid arterial remodeling in young rats. American Journal of Pathology 2005 167 1429-1442. (https://doi.org/10.1016/S0002-9440(10)61229-1)

$80 \mathrm{Li}$ Z, Froehlich J, Galis ZS \& Lakatta EG. Increased expression of matrix metalloproteinase- 2 in the thickened intima of aged rats. Hypertension 199933 116-123.

81 Spinetti G, Wang M, Monticone R, Zhang J, Zhao D \& Lakatta EG. Rat aortic MCP-1 and its receptor CCR2 increase with age and alter vascular smooth muscle cell function. Arteriosclerosis, Thrombosis, and Vascular Biology 200424 1397-1402. (https://doi.org/10.1161/01. ATV.0000134529.65173.08)

82 Wang M, Zhang J, Jiang LQ, Spinetti G, Pintus G, Monticone R, Kolodgie FD, Virmani R \& Lakatta EG. Proinflammatory profile within the grossly normal aged human aortic wall. Hypertension 200750 219-227. (https://doi.org/10.1161/ HYPERTENSIONAHA.107.089409)

83 Jung FF, Kennefick TM, Ingelfinger JR, Vora JP \& Anderson S. Downregulation of the intra renal renin-angiotensin system in the aging rat. Journal of the American Society of Nephrology 19945 1573-1580.

84 Yoon HE, Kim EN, Kim MY, Lim JH, Jang IA, Ban TH, Shin SJ, Park CW, Chang YS \& Choi BS. Age-associated changes in the vascular renin-angiotensin system in mice. Oxidative Medicine and Cellular Longevity 20162016 6731093. (https://doi. org/10.1155/2016/6731093)

85 Weidmann P, De Myttenaere-Bursztein S, Maxwell MH \& de Lima J. Effect on aging on plasma renin and aldosterone in normal man. Kidney International 19758 325-333.

86 Noth RH, Lassman MN, Tan SY, Fernandez-Cruz Jr A \& Mulrow PJ. Age and the renin-aldosterone system. Archives of Internal Medicine 1977137 1414-1417. (https://doi.org/10.1001/archinte.137.10.1414)

87 Eggena P, Morin AM, Barrett JD \& Krall JF. The influence of aging on angiotensinogen production by rat vascular smooth muscle cells in vitro. Clinical and Experimental Hypertension: Part A, Theory and Practice 198810 597-603. (https://doi. org/10.3109/10641968809033912)

88 Badreh F, Joukar S, Badavi M \& Rashno M. Restoration of the renin-angiotensin system balance is a part of the effect of fasting on cardiovascular rejuvenation: role of age and fasting models. Rejuvenation Research 202023 302-312. (https://doi.org/10.1089/ rej.2019.2254)

89 Froogh G, Pinto JT, Le Y, Kandhi S, Aleligne Y, Huang A \& Sun D. Chymase-dependent production of angiotensin II: an old enzyme in old hearts. American Journal of Physiology: Heart and Circulatory
Physiology 2017312 H223-H231. (https://doi.org/10.1152/ ajpheart.00534.2016)

90 Levick SP, Melendez GC, Plante E, McLarty JL, Brower GL \& Janicki JS. Cardiac mast cells: the centrepiece in adverse myocardial remodelling. Cardiovascular Research 201189 12-19. (https://doi. org/10.1093/cvr/cvq272)

91 Gonzalez AA, Gallardo M, Cespedes C \& Vio CP. Potassium intake prevents the induction of the renin-angiotensin system and increases medullary ACE2 and COX-2 in the kidneys of angiotensin II-dependent hypertensive rats. Frontiers in Pharmacology 201910 1212. (https://doi.org/10.3389/fphar.2019.01212)

92 Wang F, Lu X, Peng K, Zhou L, Li C, Wang W, Yu X, Kohan DE, Zhu SF \& Yang T. COX-2 mediates angiotensin II-induced (pro) renin receptor expression in the rat renal medulla. American Journal of Physiology: Renal Physiology 2014307 F25-F32. (https://doi. org/10.1152/ajprenal.00548.2013)

93 Schulman IH, Zhou MS, Treuer AV, Chadipiralla K, Hare JM \& Raij L. Altered renal expression of angiotensin II receptors, renin receptor, and ACE-2 precede the development of renal fibrosis in aging rats. American Journal of Nephrology 201032 249-261. (https://doi. org/10.1159/000318607)

94 Xie X, Chen J, Wang X, Zhang F \& Liu Y. Age- and gender-related difference of ACE2 expression in rat lung. Life Sciences $2006 \mathbf{7 8}$ 2166-2171. (https://doi.org/10.1016/j.lfs.2005.09.038)

95 Chen J, Jiang Q, Xia X, Liu K, Yu Z, Tao W, Gong W \& Han JJ. Individual variation of the SARS-CoV-2 receptor ACE2 gene expression and regulation. Aging Cell 202019 e13168. (https://doi. org/10.1111/acel.13168)

96 Joshi S, Gomez S, Duran-Mendez M, Quiroz-Olvera J, Garcia C \& Jarajapu YPR. Aging healthy, or with diabetes, is associated with ACE2/ACE imbalance in the hematopoietic stem progenitor cells. FASEB Journal 2019 (supplement) 33 514.7. (https://doi.org/10.1096/ fasebj.2019.33.1_supplement.514.7)

97 Willard LCHF \& Willard HF. X-inactivation profile reveals extensive variability in X-linked gene expression in females. Nature 2005434 400-404. (https://doi.org/10.1038/nature03479)

98 Koike G, Horiuchi M, Yamada T, Szpirer C, Jacob HJ \& Dzau VJ. Human type 2 angiotensin II receptor gene: cloned, mapped to the $\mathrm{X}$ chromosome, and its mRNA is expressed in the human lung. Biochemical and Biophysical Research Communications 1994203 1842-1850.

99 Li Y, Li XH \& Yuan H. Angiotensin II type-2 receptor-specific effects on the cardiovascular system. Cardiovascular Diagnosis and Therapy 20122 56-62. (https://doi.org/10.3978/j.issn.2223-3652.2012.02.02)

100 Milsted A, Underwood AC, Dunmire J, DelPuerto HL, Martins AS, Ely DL \& Turner ME. Regulation of multiple renin-angiotensin system genes by Sry. Journal of Hypertension 201028 59-64. (https:// doi.org/10.1097/HJH.0b013e328332b88d)

101 Sampson AK, Jennings GL \& Chin-Dusting JP. Y are males so difficult to understand? A case where ' $\mathrm{X}$ ' does not mark the spot. Hypertension 201259 525-531. (https://doi.org/10.1161/ HYPERTENSIONAHA.111.187880)

102 Ji H, Zheng W, Wu X, Liu J, Ecelbarger CM, Watkins R, Arnold AP \& Sandberg K. Sex chromosome effects unmasked in angiotensin II-induced hypertension. Hypertension 201055 1275-1282. (https:// doi.org/10.1161/HYPERTENSIONAHA.109.144949)

103 Liu J, Ji H, Zheng W, Wu X, Zhu JJ, Arnold AP \& Sandberg K. Sex differences in renal angiotensin converting enzyme 2 (ACE2) activity are $17 \mathrm{~b}$-oestradioldependent and sex chromosome-independent. Biology of Sex Differences 20101 6. (https://doi.org/10.1186/20426410-1-6)

104 Araujo FC, Milsted A, Watanabe IK, Del Puerto HL, Santos RA, Lazar J, Reis FM \& Prokop JW. Similarities and differences of X and Y chromosome homologous genes, SRY and SOX3, in regulating the renin-angiotensin system promoters. Physiological Genomics 201547 177-186. (https://doi.org/10.1152/physiolgenomics.00138.2014)

This work is licensed under a Creative Commons Attribution-NonCommercial 4.0 International License. ded from Bioscientifica com at 04/26/2023 10:25:52AM 
105 Prokop JW, Watanabe IK, Turner ME, Underwood AC, Martins AS $\&$ Milsted A. From rat to human: regulation of renin-angiotensin system genes by sry. International Journal of Hypertension 20122012 724240. (https://doi.org/10.1155/2012/724240)

106 White MC, Fleeman R \& Arnold AC. Sex differences in the metabolic effects of the renin-angiotensin system. Biology of Sex Differences 2019 10 31. (https://doi.org/10.1186/s13293-019-0247-5)

107 Harvey PJ, Morris BL, Miller JA \& Floras JS. Estradiol induces discordant angiotensin and blood pressure responses to orthostasis in healthy postmenopausal women. Hypertension 200545 399-405. (https://doi.org/10.1161/01.HYP.0000157161.78721.5c)

108 Danser AH, Derkx FH, Schalejamp MA, Hense HW, Riegger GA \& Schunkert H. Determinants of interindividual variation of renin and prorenin concentrations: evidence for a sexual dimorphism of (pro)renin levels in humans. Journal of Hypertension 199816 853-862.

109 Fischer M, Baessler A \& Schunkert H. Renin angiotensin system and gender differences in the cardiovascular system. Cardiovascular Research 200253 672-677. (https://doi.org/10.1016/s00086363(01)00479-5)

110 Komukai K, Mochizuki S \& Yoshimura M. Gender and the renin-angiotensin-aldosterone system. Fundamental and Clinical Pharmacology 201024 687-698. (https://doi.org/10.1111/j.14728206.2010.00854.x)

111 Brosnihan KB, Weddle D, Anthony MS, Heise C, Li P \& Ferrario CM. Effects of chronic hormone replacement on the renin-angiotensin system in cynomolgus monkeys. Journal of Hypertension $1997 \mathbf{1 5}$ 719-726. (https://doi.org/10.1097/00004872-199715070-00003)

112 Dean SA, Tan J, O'Brien ER \& Leenen FH. 17Beta-estradiol downregulates tissue angiotensin-converting enzyme and ANG II type 1 receptor in female rats. American Journal of Physiology: Regulatory, Integrative and Comparative Physiology 2005288 R759-R766. (https://doi.org/10.1152/ajpregu.00595.2004)

113 Ichikawa J, Sumino H, Ichikawa S \& Ozaki M. Different effects of transdermal and oral hormone replacement therapy on the renin-angiotensin system, plasma bradykinin level, and blood pressure of normotensive postmenopausal women. American Journal of Hypertension 200619 744-749. (https://doi.org/10.1016/j. amjhyper.2005.10.006)

114 Xu X, Xiao JC, Luo LF, Wang S, Zhang JP, Huang JJ, Liu ML, Liu CG, $\mathrm{Xu} \mathrm{KQ}, \mathrm{Li}$ YJ, et al. Effects of ovariectomy and 17beta-estradiol treatment on the renin-angiotensin system, blood pressure, and endothelial ultrastructure. International Journal of Cardiology 2008 130 196-204. (https://doi.org/10.1016/j.ijcard.2007.08.041)

115 Macova M, Armando I, Zhou J, Baiardi G, Tyurmin D, LarrayozRoldan IM \& Saavedra JM. Estrogen reduces aldosterone, upregulates adrenal angiotensin II AT2 receptors and normalizes adrenomedullary Fra-2 in ovariectomized rats. Neuroendocrinology 200888 276-286. (https://doi.org/10.1159/000150977)

116 Mishra JS, Hankins GD \& Kumar S. Testosterone downregulates angiotensin II type-2 receptor via androgen receptor-mediated ERK1/2 MAP kinase pathway in rat aorta. Journal of the ReninAngiotensin-Aldosterone System 2016171470320316674875. (https:// doi.org/10.1177/1470320316674875)

117 O'Hagan TS, Wharton W \& Kehoe PG. Interactions between oestrogen and the renin angiotensin system - potential mechanisms for gender differences in Alzheimer's disease. American Journal of Neurodegenerative Disease 20121 266-279.

118 Hilliard LM, Sampson AK, Brown RD \& Denton KM. The 'his and hers' of the renin-angiotensin system. Current Hypertension Reports 201315 71-79.

119 Bukowska A, Spiller L, Wolke C, Lendeckel U, Weinert S, Hoffmann J, Bornfleth P, Kutschka I, Gardemann A, Isermann B, et al. Protective regulation of the ACE2/ACE gene expression by estrogen in human atrial tissue from elderly men. Experimental Biology and Medicine 2017 242 1412-1423. (https://doi.org/10.1177/1535370217718808)

120 Freshour JR, Chase SE \& Vikstrom KL. Gender differences in cardiac ACE expression are normalized in androgen-deprived male mice. American Journal of Physiology: Heart and Circulatory Physiology 2002 283 H1997-H2003.

121 Tignanelli CJ, Ingraham NE, Sparks MA, Reilkoff R, Bezdicek T, Benson B, Schacker T, Chipman JG \& Puskarich MA. Antihypertensive drugs and risk of COVID-19? Lancet: Respiratory Medicine 20208 e30-e31. (https://doi.org/10.1016/S22132600(20)30153-3)

122 Vaduganathan M, Vardeny O, Michel T, McMurray JJV, Pfeffer MA \& Solomon SD. Renin-angiotensin-aldosterone system inhibitors in patients with Covid-19. New England Journal of Medicine 2020382 1653-1659. (https://doi.org/10.1056/NEJMsr2005760)

123 Fosbol EL, Butt JH, Ostergaard L, Andersson C, Selmer C, Kragholm K, Schou M, Phelps M, Gislason GH, Gerds TA, et al. Association of angiotensin-converting enzyme inhibitor or angiotensin receptor blocker use with COVID-19 diagnosis and mortality. JAMA 2020324 168-177. (https://doi.org/10.1001/ jama.2020.11301)

124 Fudim M, Qadri YJ, Ghadimi K, MacLeod DB, Molinger J, Piccini JP, Whittle J, Wischmeyer PE, Patel MR \& Ulloa L. Implications for neuromodulation therapy to control inflammation and related organ dysfunction in COVID-19. Journal of Cardiovascular Translational Research 202013 894-899. (https://doi.org/10.1007/s12265-02010031-6)

125 De Virgiliis F \& Di Giovanni S. Lung innervation in the eye of a cytokine storm: neuroimmune interactions and COVID-19. Nature Reviews: Neurology 202016 645-652. (https://doi.org/10.1038/ s41582-020-0402-y)

126 Bonaz B, Sinniger V \& Pellissier S. Targeting the cholinergic antiinflammatory pathway with vagus nerve stimulation in patients with Covid-19? Bioelectronic Medicine 20206 15. (https://doi.org/10.1186/ s42234-020-00051-7)

127 Russo P, Bonassi S, Giacconi R, Malavolta M, Tomino C \& Maggi F. COVID-19 and smoking: is nicotine the hidden link? European Respiratory Journal 202055 2001116. (https://doi. org/10.1183/13993003.01116-2020)

128 Leung JM, Yang CX, Tam A, Shaipanich T, Hackett TL, Singhera GK, Dorscheid DR \& Sin DD. ACE-2 expression in the small airway epithelia of smokers and COPD patients: implications for COVID19. European Respiratory Journal 202055 2000688. (https://doi. org/10.1183/13993003.00688-2020)

129 Boehmer Tegan K, DeVies J, Caruso E, van Santen Katharina L, Tang S, Black Carla L, et al. Changing age distribution of the COVID19 pandemic - United States, May-August 2020. Morbidity and Mortality Weekly Report 202069 1404-1409.

Received in final form 4 December 2020

Accepted 11 December 2020

Accepted Manuscript published online 16 December 2020 https://vb.bioscientifica.com

https://doi.org/10.1530/VB-20-0014 (c) 2021 The authors Published by Bioscientifica Ltd

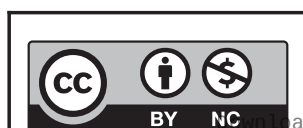

This work is licensed under a Creative Commons Attribution-NonCommercial 4.0 International License. ded from Bioscientifica com at 04/26/2023 10:25:52AM 